\title{
The influence of a dam reservoir on water quality in a small lowland river
}

\author{
Katarzyna Dębska • Beata Rutkowska • \\ Wiesław Szulc
}

Received: 15 December 2020 / Accepted: 26 January 2021 /Published online: 15 February 2021

(C) The Author(s) 2021

\begin{abstract}
The paper presents the effects of the dam reservoir in Komorów on the water quality in the Utrata river. The implementation of the adopted objective involved a comparison of water quality at two points, above and below the reservoir. The Utrata River is polluted with biogenic compounds throughout the whole section studied. COD content also indicates significant contamination exceeding permissible limits. A positive effect of the reservoir on water quality in the river was also observed in terms of the content of dissolved oxygen, with concentration increasing below the reservoir. The reservoir had a positive effect on reducing the concentration of total phosphorus in the water. Water in the Utrata below the reservoir showed higher values of chemical oxygen demand $\left(\mathrm{COD}_{\mathrm{Mn}}\right)$ than above the reservoir. There were no differences in the concentration of $\mathrm{NH}_{4}{ }^{+}$and $\mathrm{NO}_{3}{ }^{-}$ions in the water before and after the reservoir.
\end{abstract}

Keywords Biogenic compounds - Chemical oxygen demand $\cdot$ Dam reservoir $\cdot$ Water pollution

\footnotetext{
K. Dębska $(\bowtie) \cdot$ B. Rutkowska · W. Szulc Institute of Agriculture, Department of Agriculture Chemistry, Warsaw, University of Life Sciences, Nowoursynowska 166, 02-787 Warsaw, Poland e-mail: katarzyna_debska@sggw.pl

B. Rutkowska

e-mail: beata_rutkowska@sggw.pl

W. Szulc

e-mail: wieslaw_szulc@sggw.pl
}

\section{Introduction}

Retention reservoirs are a very important element of water management and a source of drinking water. They contribute to the improvement of water conditions during draughts and reduce flood flows by retaining water (Wiatkowski, 2011a, 2011b). Lakes and retention reservoirs also affect the quality of the rivers flowing through them, and the magnitude of the effect depends on the depth, size, as well as cleanliness of the rivers flowing into the water reservoir (Kijowska - Strugała, 2016).

Catchment management and therefore proper use, reclamation and protection of lakes and retention reservoirs are keys for the preservation of the natural ecosystems of rivers and water for municipal and economic purposes (Krengel et al., 2018). Pollutants transported by overland flow from built-up areas are one of the causes of the worsening of water quality (Gnecco et al., 2005). In the case of catchments of lowland rivers, water quality is usually considerably affected by agriculture, contributing to the supply and increased concentration of nutrients in rivers. Total phosphorus and nitrates have a very negative effect on the water quality in rivers and lakes they flow through. Historically, the period in which waters were most threatened was spring, due to higher than average water flow, activating phosphorus deposited in the bottom sediments of the reservoirs and increasing supply from the catchment. Over the recent years, however, draughts in the spring periods 
have caused a change in these dynamics (Górski et al., 2019). International research shows that in Poland, a considerable part of the phosphorus load is supplied to flowing waters by agriculture (Mekonnen \& Hoekstra, 2017). In recent years in Poland, pollution of flowing waters from point-based sources has been substantially reduced. Many wastewater treatment plants were constructed and modernised. Therefore, surface pollutants from agriculture constitute the primary source of nitrate nitrogen (Szalińska et al., 2018; Burzyńska, 2019).

The objective of the study was the analysis of the effect of the retention reservoir on changes in the values of selected water quality indicators in the Utrata River.

\section{Methods}

\section{Description of the area study}

The reservoir in Komorów is located in the Utrata River valley between the Komorów and Małe Pęcice villages, in the Pruszkowski poviat (Mazovian Voivodeship) $52^{\circ} 08^{\prime} 21.1^{\prime \prime} \mathrm{N} \mathrm{20} 49^{\prime} 54.8^{\prime \prime} \mathrm{E}$ (Fig. 1).

A mill functioned in the area of the modern reservoir, and water was accumulated there already before World War 2, although the retention reservoir itself was constructed in 1992. The surface area of the reservoir is approximately 6 ha. The Utrata

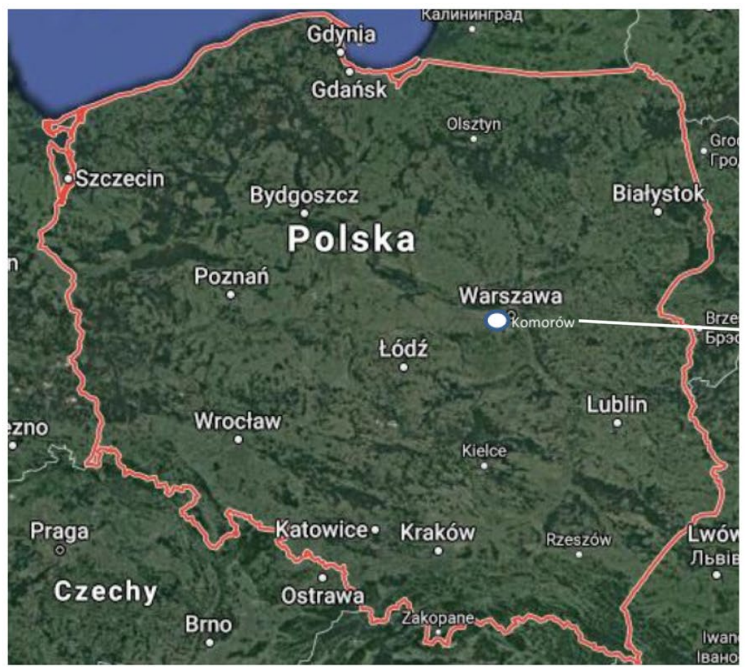

River flows into the reservoir from the south and flows out to the north through a dam. The reservoir is located between Pęcice and Komorów and was formed through water damming. In addition to its retention purpose, the reservoir also fulfils recreational functions. A playground is located on its northern side. The reservoir in Komorów plays a very important role in the reduction of flood flow. The catchment area above the reservoir is $114.5 \mathrm{~km}^{2}$. Water reservoirs on the river contribute to limiting the load of pollutants flowing through it. The Utrata River, on which the analysed retention reservoir functions, is a right-bank tributary of the Bzura River to which it flows in Sochaczew, has a length of $78 \mathrm{~km}$, and catchment area of $702 \mathrm{~km}^{2}$. The Utrata is exposed to pollution from the following sources: fish ponds, wastewater treatment plants, heat and power plants, waste dumps and progressing urbanisation. Another important source of pollutants supplied to the river is agriculture, which provides Warsaw with food. A considerable part of the catchment is occupied by Gleyic Phaeozems (WRB World reference base for soil resources 2014) (Kabała et al., 2019). Due to this, agriculture in the area is strongly developed and specialised (Wojtkowska, 2006). Water samples for physicochemical analyses were collected from the Utrata River above (control-measurement point 1) and below (control-measurement point 2) the reservoir every month throughout the hydrological year, i.e., in the period from April 2018 to March 2019.

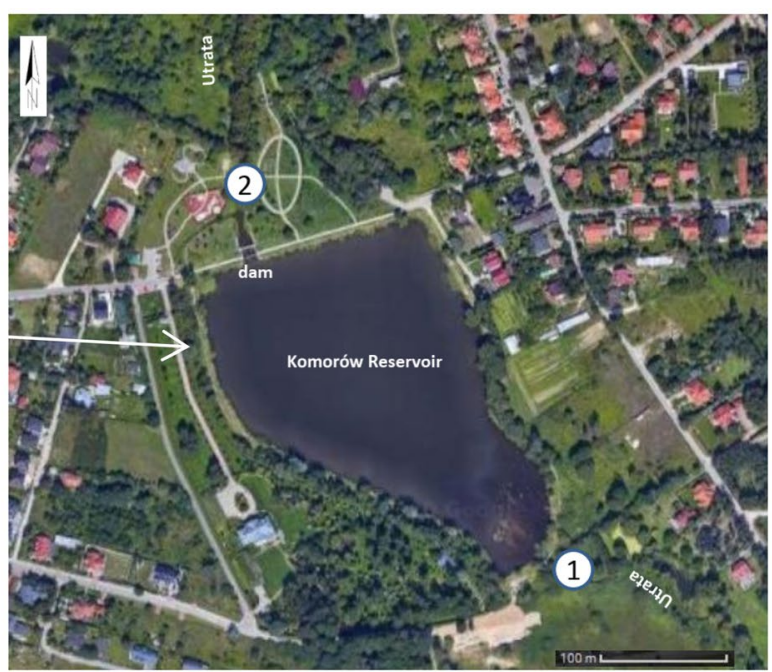

Fig. 1 Study area-location control-measurement points 1 and 2 in the Komorów reservoir 


\section{Chemical analysis}

The following parameters were analysed (Fig. 1):

- $\mathrm{pH}$ according to norm PN-EN ISO 10523:2012.

- Temperature

- Dissolved oxygen according to the norm PN-EN 25813:1997

- Chemical oxygen demand according to the norm PN-EN ISO 8467:2001

- Total phosphorus according to the norm PN-EN ISO 6878:2006

- Ammonia nitrogen and nitrate nitrogen by the flow-through method according to the norm PN-EN ISO 11732:2007.
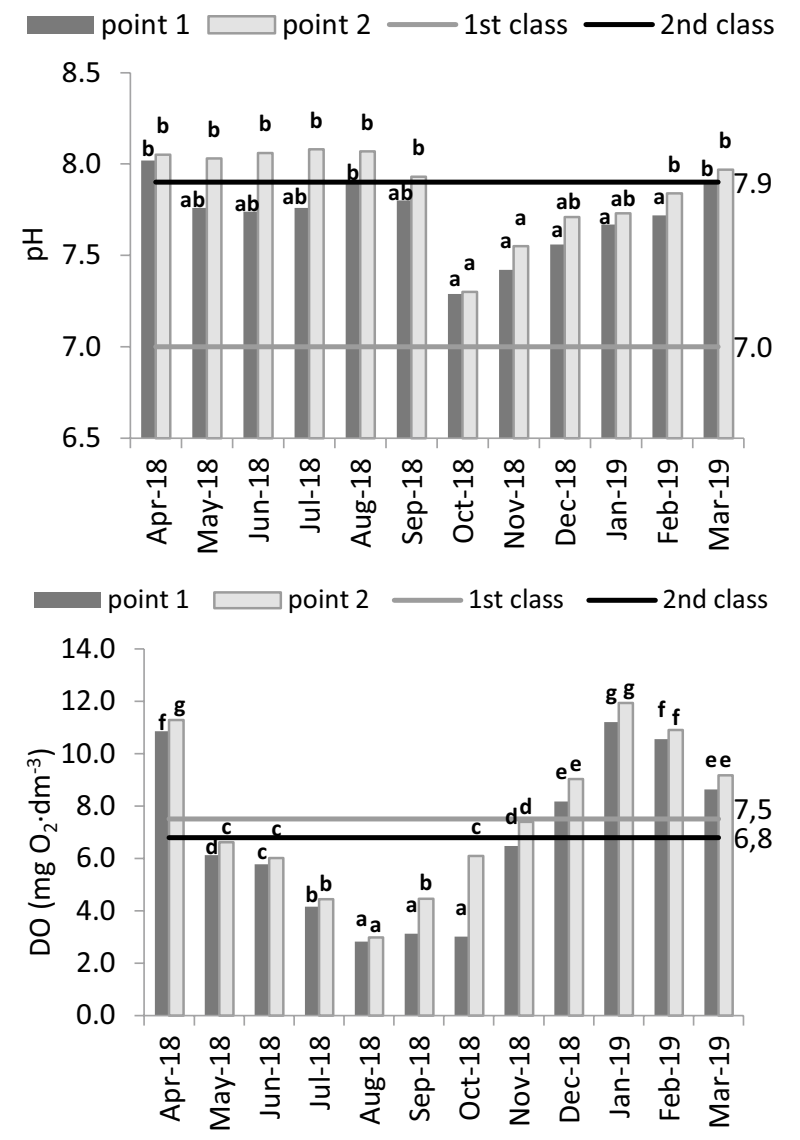

\section{Statistical analysis}

For the statistical processing of the obtained results, a multifactorial analysis of variance (ANOVA) was applied. The determination of the significance of differences between mean values was employed using Tukey's test, at a significance level of $p=0.05$. The statistical analysis of results was performed with the application: Statistica ver. 10 software.

\section{Results}

The $\mathrm{pH}$ value was determined to be subject to considerable changes throughout the year. The lowest $\mathrm{pH}$ was recorded in October at control-measurement point $1 \mathrm{pH}=7.29$, and the highest values were observed at point 2 in July $\mathrm{pH}=8.08$ (Fig. 2).
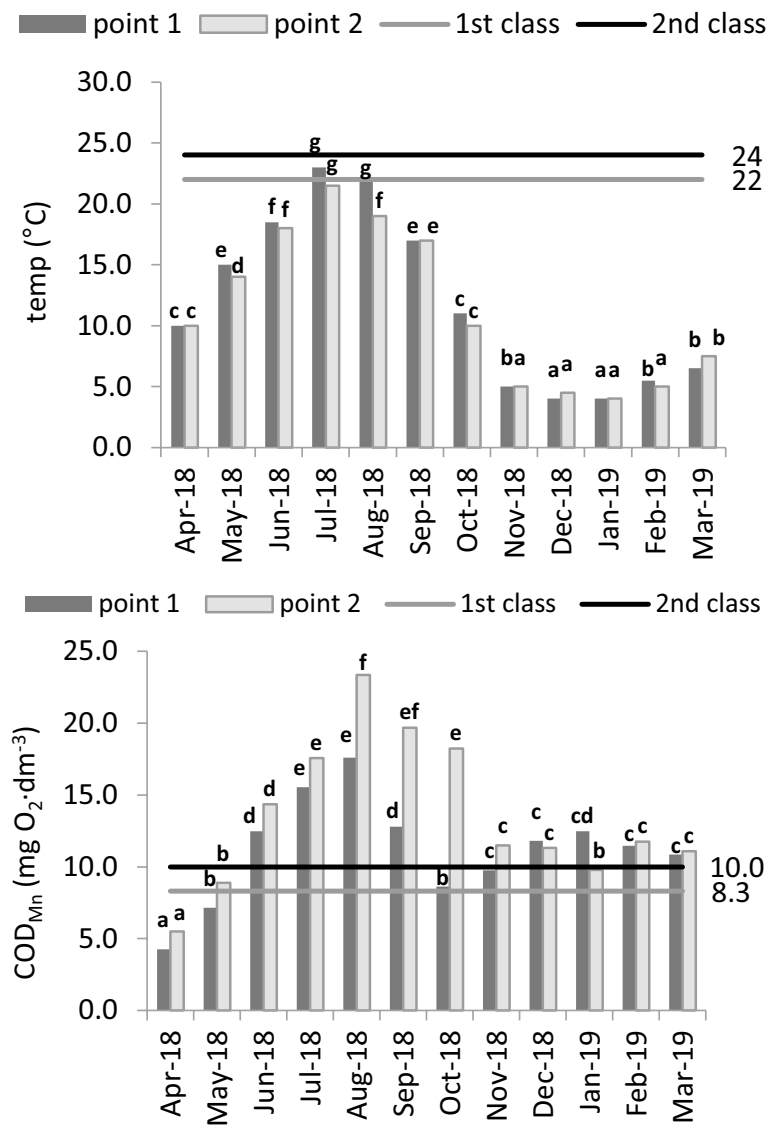

Fig. 2 Seasonal variability of the $\mathrm{pH}$, temperature, concentration of dissolved oxygen, COD in Utrata river, ranges of 1 st and 2 nd class of water quality according to Regulation of the Minister of the Environment of July 21 (2016) 
In all sampling terms, water showed higher $\mathrm{pH}$ values after leaving the reservoir. In the autumn and winter months (October to February), the $\mathrm{pH}$ value was within the ranges defined for water quality class I, while from March to September, the $\mathrm{pH}$ value exceeded the limits defined as water quality class II. Water temperature was strongly variable throughout the study period. The highest values were recorded in July $\left(23{ }^{\circ} \mathrm{C}\right)$, and it was the only measurement that exceeded the threshold values of class I water quality. The lowest temperature values were measured in December and January and equalled $4{ }^{\circ} \mathrm{C}$. The Komorów reservoir influenced the temperature reduction in the Urata River in the months of May, June, July, August, October and February. A temperature increase in the river below the reservoir occurred in December, January and March. Dissolved oxygen concentration was variable depending on the season and measurement point. The highest value of the index $\left(11.94 \mathrm{mg} \mathrm{O}_{2} \mathrm{dm}^{-3}\right)$ was observed in January, at the measurement point behind the reservoir. The value did not exceed the threshold values for class I of water cleanliness. The lowest dissolved oxygen concentration was measured in August at the point in front of the reservoir $(2.83 \mathrm{mg}$ $\mathrm{O}_{2} \mathrm{dm}^{-3}$ ). The value exceeded the threshold of class II of water quality. The concentration of oxygen in the Utrata River increased below the Komorów reservoir during each test period. The chemical oxygen demand, pointing to water pollution with organic substances, was strongly variable depending on the season and site. The lowest values were observed in April, and the strongest pollution was recorded in August, when the threshold value for class II of water cleanliness was exceeded. Except for the winter months (December-January), the concentration of the COD index was higher at the point below the Komorów reservoir.

Total phosphorus concentration was very high, and considerably exceeded the permissible threshold values for class II of water quality. The highest values were measured in summer months $-4.6 \mathrm{mg} \mathrm{P} \mathrm{dm}^{-3}$ in July—and the lowest in April- $0.3 \mathrm{mg} \mathrm{P} \mathrm{dm}^{-3}$ (Fig. 3). For the majority of the year, the reservoir contributed to a decrease in the quantity of pollutants flowing in the river. Only in summer months (July, August, September), the total phosphorus concentration was higher at the measurement point above, rather than below the reservoir. The concentration of ammonium nitrogen showed variability over the study period. The lowest values of the index occurred in spring months (April-0.13 mg N-NH $\mathrm{dm}^{-3}$ ) and the highest in summer and autumn months (September-1.41 mg $\mathrm{N}-\mathrm{NH}_{4} \mathrm{dm}^{-3}$ ) (Fig. 3). No significant influence of the retention reservoir of Komorów on ammonium nitrogen concentration in the Utrata River was observed. Ammonium nitrogen concentration decreased behind the reservoir in June, September, November, December, January, February and March; however, ammonium nitrogen concentration increased in April, May, July, August and October. The concentration of nitrate nitrogen was strongly variable over the study period. The lowest values were observed in September (point $1-2.05 \mathrm{mg} \mathrm{N}-\mathrm{NO}_{3} \mathrm{dm}^{-3}$; point $2-13 \mathrm{mg} \mathrm{N}-\mathrm{NO}_{3} \mathrm{dm}^{-3}$ ) and the highest in January (point $1-5.8 \mathrm{mg} \mathrm{N}-\mathrm{NO}_{3} \mathrm{dm}^{-3}$; point $2-5.6 \mathrm{mg}$ $\mathrm{N}-\mathrm{NO}_{3} \cdot \mathrm{dm}^{-3}$ ). The Komorów Reservoir showed no considerable effect on changes in the concentration of nitrate and ammonia nitrogen in the Utrata river. In the winter months, the concentration of nitrate nitrogen was the highest, and the lowest concentration was observed in the autumn months.

\section{Discussion}

In terms of the index, water in the Utrata River showed values exceeding those limits for class II of water quality. A general cause of higher than average $\mathrm{pH}$ can be sewage discharge to rivers, showing a particularly strong effect in warm months, when the water table is low. A cause of higher than average $\mathrm{pH}$ at point 2 as compared with point 1 can be development of algae reducing the content of $\mathrm{CO}_{2}$ in water. Similar $\mathrm{pH}$ results were observed by Adedeji et al., (2019) and Kuchko et al. (2020). Temperature below the reservoir in summer months was lower or equal to the value measured above the reservoir. Łaszewski et al. in 2018 showed that in the summer months, the temperature below the reservoir is higher than above the reservoir, which is at variance with the study results. It should be emphasised, however, that the Utrata in front of the reservoir in Komorów is not a regulated river. It flows slowly in a shallow channel, and therefore heats up much faster. Also, Jonczak and Parzych (2019), while studying Kamienna Stream, did not observe the influence of the reservoir on the water temperature in the river. 

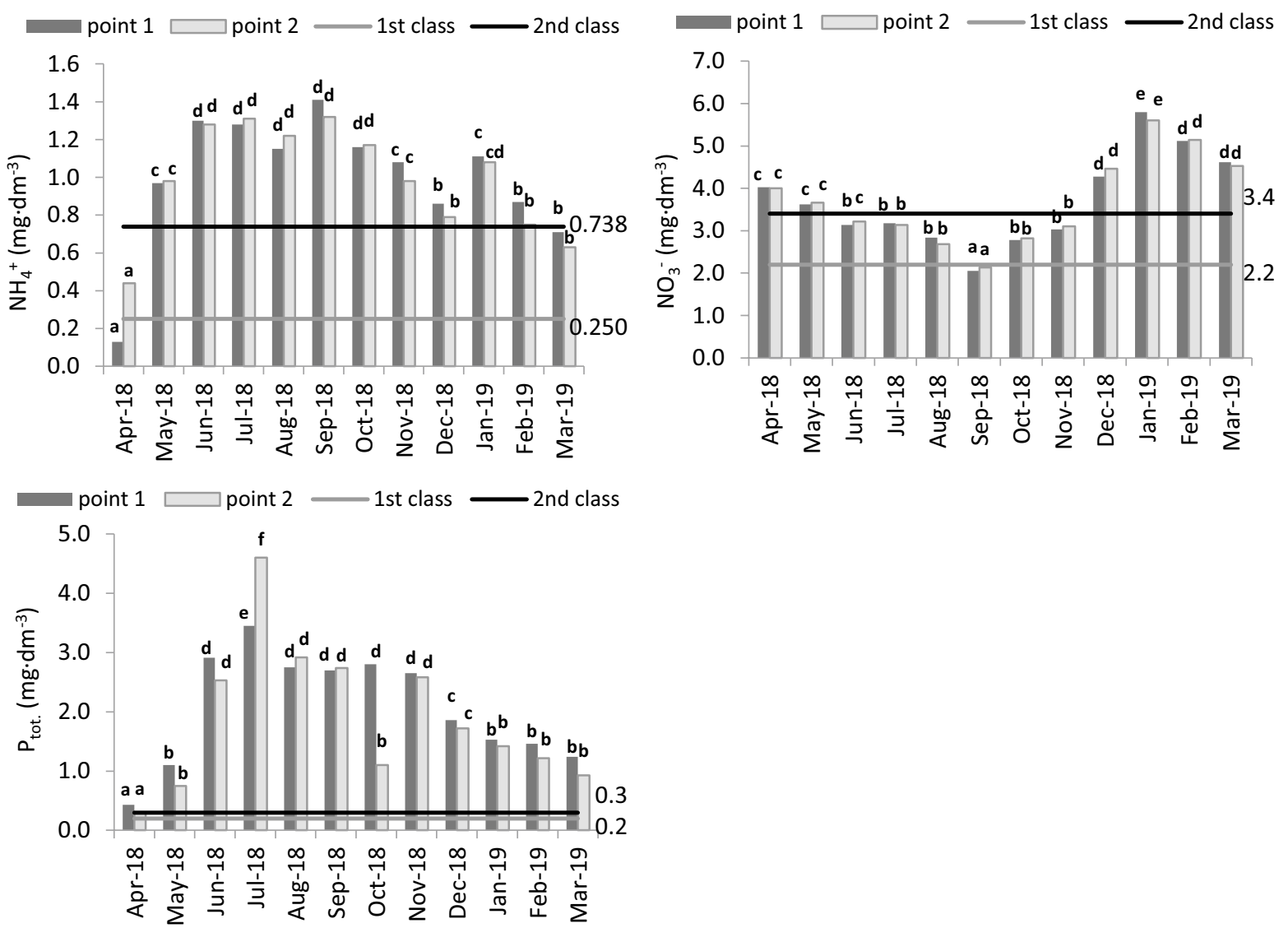

Fig. 3 Seasonal variability of the of ammonium, nitrate (V) and total phosphorus concentration in the Utrata river, ranges of 1 st and 2nd class of water quality according to Regulation of the Minister of the Environment of July 21 (2016)

Throughout the study period, oxygen concentration was usually higher at the measurement point behind the Komorów Reservoir. Dissolved oxygen concentration in surface waters depends on many factors. It increases due to the process of photosynthesis and reaeration. A reduction of dissolved oxygen concentration can be caused by a higher than average temperature and mineralisation of organic substances (Rajwa-Kuligiewicz et al., 2015). In the case of the Utrata, the temperature at the point behind the reservoir is lower; this may increase the dissolved oxygen concentration. Another probable cause of the dissolved oxygen concentration increase is a dam situated at the river outlet, which causes mechanical aeration of the water. Ziułkiewicz (2019) also observed an increase in the dissolved oxygen concentration and chemical oxygen demand in the river after leaving the reservoir. An increase in the concentration of organic pollutants measured by the
CODMn index was observed in the summer months. It may be associated with a higher than average quantity of pollutants of agricultural or municipal origin ( $\mathrm{Yu}$ $\& \mathrm{Wu}, 2018)$. The chemical oxygen demand value was always higher at the measurement point below the Komorów Reservoir. Notice the correlation, however, between the content of dissolved oxygen and value of chemical oxygen demand. When the content of the dissolved oxygen in water decreases, the chemical oxygen demand considerably increases, because of the lack of oxidant that would oxidise the reduced organic pollutants. Decreasing the speed of the water in the river flowing through the reservoir results in the sedimentation of nutrients at the bottom (Verstraeten \& Poesen, 2000); however, in the case of the river Utrata, such dependence does not occur. This may be due to the high content of organic substances in the lake, which makes the sedimentation process difficult. A clear increase in the 
organic matter concentration at points below the reservoir can be observed at the end of the growing season, due to internal feeding from the bottom sediment of the Komorów reservoir. Due to its location, the Komorów reservoir may be exposed to the following sources of phosphorus: agriculture, urbanisation and sewage disposal. The causes of such high total phosphorus concentration are pollutants of agricultural and municipal origin (Wojtkowska \& Bojanowski, 2018). Other sources of phosphorus in rivers can be the grazing of animals and unregulated sewage management (Ilić \& Panjan, 2018). Organic pollutants flowing into the reservoir for many years have been deposited at the bottom, significantly increasing the potential of the internal charge (Qin et al., 2020). The presence of a weir in front of the discharge of water from the reservoir can disturb sediment deposition (Moore et al., 2012). Six kilometres above the reservoir, there is a sewage treatment plant in Walendow, which may affect the high concentration of ammonium nitrogen in the waters of the river Utrata before entering the Komorów reservoir. Another potential source of ammonium nitrogen is runoff from agricultural land and the decomposition of organic substances. In flowing waters, as a result of decomposition of organic substances, ammonia occurs. It is strongly bioavailable, contributing to the development of phytoplankton. Another source of ammonia nitrogen can be industrial and municipal sewage (Burzyńska, 2019). Measurements performed by the National Geological Institute determine ammonium nitrogen concentration in a range of 0.18-0.8 $\mathrm{mg} \quad \mathrm{N}_{-} \mathrm{NH}_{4} \quad \mathrm{dm}^{-3}$ in the Utrata river. Wiatkowski (2011a) evidenced that water reservoirs contribute to a decrease in the pollution of rivers flowing through them through the sedimentation process. In the case of the reservoir in Komorów, no such unambiguous dependency was determined, suggesting its high level of pollution. For most of the year, the studied reservoir reduced ammonium nitrogen concentration in the Utrata river, and a similar correlation was observed by Liu et al. (2019).

\section{Conclusion}

The water quality in the Utrata River was the most negatively affected by nutrients, particularly by total phosphorus concentration. For the majority of the year, the Komorów Reservoir constituted no barrier for pollutants supplied through the Utrata River, as manifested in an increase in the value of CODMn and lack of $\mathrm{N}-\mathrm{NH}_{4}, \mathrm{~N}_{-} \mathrm{NO}_{3}$ concentration change in the river below the reservoir. The Komorów Reservoir positively affects the concentration of dissolved oxygen, decreases total $\mathrm{P}$ concentration and increases water $\mathrm{pH}$ and reduces the temperature in the summer months.

Open Access This article is licensed under a Creative Commons Attribution 4.0 International License, which permits use, sharing, adaptation, distribution and reproduction in any medium or format, as long as you give appropriate credit to the original author(s) and the source, provide a link to the Creative Commons licence, and indicate if changes were made. The images or other third party material in this article are included in the article's Creative Commons licence, unless indicated otherwise in a credit line to the material. If material is not included in the article's Creative Commons licence and your intended use is not permitted by statutory regulation or exceeds the permitted use, you will need to obtain permission directly from the copyright holder. To view a copy of this licence, visit http://creativecommons.org/licenses/by/4.0/.

\section{References}

Adedeji, H., Idowu, T., Usman, M., \& Sogbesan, O. (2019). Seasonal variations in the physico-chemical parameters of Lake Ribadu. Adamawa state Nigeria, International Journal of Fisheries and Aquatic Studies, 7(1), 79-82.

Burzyńska, I. (2019). Monitoring of selected fertilizer nutrients in surface waters and soils of agricultural land in the river valley in Central Poland. Journal of Water and Land Development, 43(9-12), 41-48. https://doi.org/10.2478/ jwld-2019-0061.

Gnecco, I., Berretta, C., Lanza, L. G., \& Barbera, La. (2005). 227 P. Storm water pollution in the urban environment of Genoa. Italy Atmospheric Research, 77(1), 60-73. https:// doi.org/10.1016/j.atmosres.2004.10.017.

Górski, J., Dragon, K., Michał, P., \& Kaczmarek, J. (2019). Nitrate pollution in the Warta River (Poland) between 1958 and 2016: trends and causes, Environmental Science and Pollution Research, 26, 2038-2046. https://doi. org/10.1007/s11356-017-9798-3 http://mapy.google.pl/

Ilić, D., \& Panjan, J. (2018). Nitrogen and phosphorus pollution in Goricko Nature Park. Acta Geographica Slovenica, 58(1), 125-136. https://doi.org/10.3986/AGS.727.

Jonczak, J., \& Parzych, A. (2019). Effect of a small retention system on the temperature and chemistry of a mid-forest headwater stream. Journal of Elementology, 24(2), 771783. https://doi.org/10.5601/jelem.2018.23.4.1733.

Kabała, C., Charzyński, P., \& Chodorowski, J. (2019). Polish Soil Classification, 6th edition -principles, classification scheme and correlations. Soil Science Annual, 70(2), 71-97 
Kijowska-Strugała, M., Wiejaczk, Ł, \& Kozłowski, R. (2016). Influence of reservoirs on the concentration of nutrients in the water of mountain rivers. Ecological Chemistry and Engineering, 23(3), 413-424. https://doi.org/10.1515/ eces-2016-0029.

Krengel, F., Bernhofer, C., Chalov, S., Efimov, V., Efimova, L., Gorbachova, L., et al. (2018). Challenges for transboundary river management in Eastern Europe - three case studies. Journal of the Geographical Society of Berlin, 149(2-3), 157-172. https://doi.org/10.12854/erde-2018-389.

Kuchko, Y., Ilmast, N., \& Kuchko, T. (2020). The State of the Lake-river System Affected By Mineral Production KnE Life Sciences / International Applied Research Conference. Biological Resources Development and Environmental Management, 152-161. https://doi. org/10.18502/kls.v5i1.6039.

Łaszewski, M. (2018). Human impact on spatial water temperature variability in lowland rivers: a case study from Central Poland. Polish Journal of Environmental Studies, 27(1), 1-10. https://doi.org/10.15244/pjoes/75174.

Liu, M., Chen, X., Chen, Y., Gao, L., \& Deng, H. (2019). Nitrogen retention effects under reservoir regulation at multiple time scales in a subtropical river basin. Water, 11(1685), 1-15. https://doi.org/10.3390/w11081685.

Mekonnen, M. M., \& Hoekstra, A. Y. (2017). Global Anthropogenic Phosphorus Loads to Freshwater and Associated Grey Water Footprints and Water Pollution Levels: A High Resolution Global Study. American Geophysical Union, 260 345-358. https://doi. org/10.1002/2017WR020448.

Moore, J. N., Arrigoni, A. S., \& Wilcox, A. C. (2012). Impacts of dams on flow regimes in three headwater subbasins of the Columbia River Basin, United States. Journal of the American Water Resources Association, 48(5), 925-936. https://doi.org/10.1111/j.1752-1688.2012.00660.x.

PN EN 25813. (1997). Water quality - determination of dissolved oxygen - iodometric method, Polish Committee for Standardization

PN EN ISO 10523. (2012). Water quality - determination of $\mathrm{pH}$ (ISO 10523:2008), Polish Committee for Standardization

PN EN ISO 6878. (2006). Water quality - determination of phosphorus - ammonium molybdate spectrometric method, Polish Committee for Standardization

PN EN ISO 8467. (2001). Water quality - determination of permanganate index, Polish Committee for Standardization

PN EN ISO 11732. (2007). Water quality - Determination of ammonium nitrogen by flow analysis (CFA and FIA) and spectrometric detection, Polish Committee for Standardization

Qin, L., Lei, P., Lei, Q., Liu, H., Li, X., Zhang, H., \& Lindsey, S. (2020). Evaluating the effect of dam construction on the phosphorus fractions in sediments in a reservoir of drinking water source. Environmental Monitoring and Assessment, 192, 99. https://doi.org/10.1007/s10661019-8053-4.

Rajwa-Kuligiewicz, A., Bialik, R. J., \& Rowiński, P. M. (2015). Dissolved oxygen and water temperature dynamics in lowland rivers over various timescales. Journal Hydrology and Hydromechanics, 63(4), 353-363. https://doi. org/10.1515/johh-2015-0041.

Regulation of the Minister of the Environment of July 21 (2016). on how to classify the status of surface water bodies and environmental quality standards for priority substances. Journal of Laws 2016 item 1187,

Szalińska, E., Orlińska-Woźniak, P., \& Wilk, P. (2018). Nitrate Vulnerable Zones Revision in Poland-Assessment of Environmental Impact and Land Use Conflicts. Sustainability, 10(9) 3297, 1-16. https://doi.org/10. 3390/su10093297.

Verstraeten, G., \& Poesen, J. (2000). Estimating 291 trap efficiency of small reservoirs and ponds: methods and implications for the assessment of sediment yield. Progress in Physical Geography, 24(2), 219-251. https:// doi.org/10.1177/030913330002400204.

Wiatkowski, M. (2011a). M. Influence of Msciwojow PreDam Reservoir on water quality in the water reservoir dam and below the reservoir. Ecological Chemistry and Engineering, A, 18, 289-300.

Wiatkowski, M. (2011b). Influence of Shup Dam Reservoir on flow and quality of water in the Nysa Szalona River. Polish Journal of Environmental Studies, 20(2), 469-478.

Wojtkowska, M. (2006). Influence of land management on surface water pollution Utrata river. Gaz, Woda i Technika Sanitarna, 11, 70-72.

Wojtkowska, M., \& Bojanowski, D. (2018). Influence of Catchment Use on the Degree of rivers Water Pollution by Forms of Phosphorus. Annual Set The Environment Protection, 20(1506- 2018X), 887-904

WRB World reference base for soil resources. (2014). Food and Agriculture Organization of the United Nations, Rome, 2015

Yu J., Wu J. (2018). The Sustainability of Agricultural Development in China. The Agriculture-Environment Nexus Sustainability, 10(6) 1776, 1-17 https://doi. org/10.3390/su10061776.

Ziułkiewicz M., Górecki M., Fortuniak A., Walas A., \& Grulke R. (2019). 24-hour nutrient mass balance of small storage reservoir included in municipal rainwater drainage system, E3S Web of Conferences, EKO-DOK 2019 100, 00093 1-8 https://doi.org/10.1051/e3sconf/201910000093.

Publisher's Note Springer Nature remains neutral with regard to jurisdictional claims in published maps and institutional affiliations. 